\title{
ENTREPRENEURSHIP EDUCATION FOR MSMES AND YOUTH ORGANIZATION (KARANG TARUNA)
}

\author{
Lukertina Sihombing, Mochamad Soelton, Eko Tama Putra Saratian, Harefan Arief, and Margono \\ Setiawan \\ Universitas Mercu Buana Jakarta, Indonesia \\ Universitas Brawijaya.
}

\begin{abstract}
According to data from the Ministry of Manpower (Menaker) in 2018 the number of entrepreneurs who grew in Indonesia rose $3.4 \%$ from the previous year of $3.1 \%$. This growth exceeds International Standards of $2 \%$. This growth rate is still very small for other ASEAN neighboring countries such as Malaysia which has grown 5\%, Thailand has grown 4\% and Singapore has grown to 7\%. Chinese entrepreneurship growth has reached $10 \%$ and Japan has reached $11 \%$. By looking at the comparison of the growth achievements of other countries, Indonesia is expected to become more competitive. To be able to achieve an increase in entrepreneurial growth, the government must work together with major companies to provide education and training entrepreneurship. Community empowerment by conducting entrepreneurship training and development aimed at Micro, Small and Medium Enterprises and Youth Youth Organization. In addition, there is also a need for training on how to get access to funding in creating a new company. As is known, one of the obstacles in creating new entrepreneurs is funding. . Entrepreneurs are considered to have a special role in innovation and bringing social change, traditionally from a macroeconomic perspective (Bosma et al, 2012).
\end{abstract}

Key words: Education, Entrepreneur, Innovation, Macroeconomic Perspective

\section{INTRODUCTION}

The SME empowerment policy in general is directed at supporting efforts to reduce poverty and inequality, create employment opportunities and increase exports, and revitalize agriculture and rural areas, which are the priority of national development in the year. In this framework, the development of small and medium enterprises (SMEs) is directed towards making a significant contribution to the creation of employment opportunities, increasing exports and increasing competitiveness, while the development of micro-scale businesses is directed to contribute to increasing the income of low-income people, especially in the sector agriculture and rural areas.

The real performance faced by most businesses, especially micro, small and medium enterprises (MSMEs) in Indonesia, which is most prominent is the low level of productivity, low value added, and low product quality. Although it is also recognized that MSMEs provide employment for the majority of workers in Indonesia, the contribution in national output is low. This is because MSMEs, particularly the microenterprise and the agricultural sector (which absorb a lot of labor), have very low productivity.

If wages are used as productivity, average wages in micro and small businesses are generally below the minimum wage. This condition reflects the low productivity of the micro and small sectors when compared to larger businesses. Among the various contributing factors, the low level of technological mastery and entrepreneurial ability among MSMEs has become a prominent issue today. The development of UMKM partially so far has not provided many maximum results to the improvement of MSME performance, economic development more broadly results in the level of our competitiveness lagging behind our neighboring countries such as Malaysia.

Therefore, the policy for MSMEs is not because of their small size, but because of their low productivity. Increased productivity at MSMEs will have a broad impact on improving people's welfare because MSMEs are a place where many people depend their livelihoods. One alternative in increasing MSME productivity is by modernizing .

According to data from the Ministry of Manpower (Menaker) in 2018 the number of entrepreneurs who grew in Indonesia rose $3.4 \%$ from the previous year of $3.1 \%$. This growth exceeds International Standards of $2 \%$. This growth rate is still very small for other ASEAN neighboring countries such as Malaysia which has grown 5\%, Thailand has grown 4\% and Singapore has grown to 7\%. Chinese entrepreneurship growth has reached $10 \%$ and Japan has reached 11\%. 
By looking at the comparison of the growth achievements of other countries, Indonesia is expected to become more competitive. To be able to achieve an increase in entrepreneurial growth, the government must work together with major companies to provide education and pelati han entrepreneurship. Community empowerment by conducting entrepreneurship training and development aimed at Micro, Small and Medium Enterprises and Youth (Karang Taruna) Organization. In addition, there is also a need for training on how to get access to funding in creating a new business. As is known, one of the obstacles in creating new entrepreneurs is funding. On the other side of the small culture of Indonesian people where the measure of success is graduating from high school or college and then getting a job.

In recent years, along with the development of sophisticated information technology through the internet and social media that emerged it has made a major contribution to the creation of new entrepreneurs. Many people have begun to use the internet and social media as their business platform. Even through social media they have created business groups or business communities.

\section{LITERATURE REVIEW}

Schumpeter's theory that capitalism develops entrepreneurship as a driving force has recently attracted more attention (Aghion and Akcigit, 2015). The Schumpeterian model presents entrepreneurship and companies as centers of economic growth. Entrepreneurship in a managed economy has a negative impact on economic growth but the entrepreneurial economy is the main driving force of growth (Armington, 2004). Failure of companies in a managed economy is considered negative and is seen as a waste of social capital. On the other hand, failure in the entrepreneurial economy is considered as a result of experimental activities and social learning.

There must be an entrepreneur innovator to drive innovation, and this is the key. So, it is necessary to make research on entrepreneurship that is more academic and political. Innovation in transition is basically dangerous and has to do with failure. Therefore, it is not important to support successful projects, not to pursue experimental innovations (Kim, 2018).

Also, there are qualitative studies about entrepreneurial research. (Joseph, Wayn, 2008) they focus on entrepreneurs in the maritime field pilot industry who want to make a difference and illustrate how professional associations that work with and through government can prevent individual members from being innovative. (Shin, 2017) learn to examine organizational processes turning into new entrepreneurship such as corporate spinoffs or intrapreneurship.

(Santandreu-Mascarell, Garzon and Knorr, 2013) revealed that one of the ways entrepreneurs contribute to economic development is through innovations that involve the growth of new products, new processes, new sources of supply, exploitation of new markets, and the development of new ways to regulate business; thus innovation can be associated with entrepreneurial intention.

(Harris and Gibson, 2008) report that students with family business experience have developed strong entrepreneurial attitudes. Families have an impact on individual entrepreneurial intentions in terms of role modeling perspectives and assume parents play an important role in their children's entrepreneurial careers. (Franke and Luthje, 2004) claim that environmental factors are facilitating entrepreneurial activities then influencing the percentage of benefits expected from new companies; hence may have an important role in shaping entrepreneurial intentions among students.

Entrepreneurship barriers include difficulties in getting institutional support for entrepreneurs who inspire, receive family support, secure financing from lenders, build relationships with suppliers and a solid customer base (Shinnar, Giacomin \& Jansen, 2012). When potential entrepreneurs are aware of a hostile environment for business founders such as limiting credit conditions, they tend to become entrepreneurs regardless of their attitude towards entrepreneurs.

The legal framework, financing and access to capital are subject to interest for entrepreneurs. The highest ranking determinant of entrepreneurial activity is access to finance and access to knowledge or training. This training uses experiential learning methods with interactive communication techniques, dialogues, discussions, role plays / games, where participants are introduced to concepts, then directly involved with feelings, experiences, discuss the process and results of this training. to generate the entrepreneurial spirit of young people in Meruya Utara area.

This training was held in collaboration with the Faculty of Economics and Business, Mercu Buana University (UMB) with MSMEs and youth organization Karang Taruna Meruya Utara. UMB helped provide speakers, seminar leaflets, pre-post examinations, evaluations, and snacks, while Karang taruna Meruya Utara helped to condition the participants, provided a place (room), and training equipment / equipment. Training participants are 30 participants in this activity. 
Phase 1: Participant's pre-test and initial assessment

After the opening ceremony and before the material was delivered, participants were asked to fill in the questionnaire as a pre-test. Initial assessment of the participants is done by filling out the training registration form.

Phase 2: Submission of training material by the instructor

The training material consists of presentations, brainstorming, brainstorming, and dialogue. The selection of this method is carried out with the aim of achieving the desired targets of successful training in developing entrepreneurship

Phase 3: Post-test and feedback

Before closing, participants are asked to fill in a post-test, and evaluate the event, messages and impressions from the participants as feedback.

\section{RESULTS AND DISCUSSION}

This community service activities consist of two training sessions that occur with the p Participants Youth North Meruya. The training method is a combination of marketing training and entrepreneurship concepts. For this activity marketing training is given by lecturers who are experts in their fields . For entrepreneurship training given by UMB lecturers. Provision of marketing supplies is given with general product marketing materials, as well as about entrepreneurship and how to work with SMART.

At the time of providing training not only stories about the theory but rather the discussion of the problems they faced so far. In the field of entrepreneurship, the training room is divided into business people who produce goods, services, and trade or sell. They can discuss the problems they have faced so far.

Then the training program was continued with FGD, about the problems faced by MSME and youth organization (Karang Taruna) related to the training needs to solve the existing problems. It turns out that the most problems are problems in the financial sector, both in its management which is still mixed with family financial management and business finance, lack of capital, difficulty in getting a network with financial institutions or banks. In the field of marketing, the problems they face are problems with the difficulty of getting a place to sell, the difficulty of expanding the market, ignorance of promotional tools and the importance of product development.

\section{CONCLUSION}

Supporting competitiveness it is necessary emphasize the importance of competitive advantage arising from creativity and good quality human resources and high competence. To be able to create competitive advantage then 3 things are needed, namely knowledge, creativity, and innovation. Knowledge will be the basis for exploring the creativity of a person or group, as the basis for various innovations. Innovations sourced from knowledge and creativity will be able to produce something new that does have characteristics certain. This will be the source of competitive advantage. Therefore the availability of good quality human capital is very much needed.

\section{REFERENCES}

Al Manun, Abdullah. Fajrah, Siti. Noorshella and Zakaria, (2017) Factors affecting entrepreneurial intention among Malaysian University Student, The journal of developing areas, Vol.51 No.6

Boer, Harry. (2001). Innovation, What Innovation? A Comparison between product, process and organizational innovation. International Journal of Technology Management - INT J TECHNOL MANAGE. 22. 83107. 10.1504/IJTM.2001.002956.

Bosma, N.S., Wennekers, S. and Amorós, J.E. (2012). Global Entrepreneurship Monitor 2011 Extended Global Report: Entrepreneurs and entrepreneurial employees across the globe, Babson Park, MA, US: Babson College, Santiago, Chile: Universidad del Desarollo, Kuala Lumpur, Malaysia: Universiti Tun Abdul Razak and London, UK: Global Entrepreneurship Research Association.

Damanpour, F. (1991). Organizational innovation: A meta-analysis of effects of determinants and moderators. Academy of Management Journal, 34(3), 555-590. http://dx.doi.org/10.2307/256406

Drucker, P. (1985). Innovation and Entrepreneurship. (MA), Cambridge 
Hult, G. T. M., Hurley, R. F., \& Knight, G. A. (2004). Innovativeness: Its antecedents and impact on business performance. Industrial Marketing Management, 33(5), 429-438.

Khazanchi, S., Lewis, M. W., \& Boyer, K. K. (2007). Innovation-supportive culture: The impact of organizational values on process innovation. Journal of operations management, 25(4), 871-884. http://dx.doi.org/10.1016/j.jom.2006.08.003

Kimberly, J. R., \& Evanisko, M. J. (1981). Organizational innovation: The influence of individual, organizational, and contextual factors on hospital adoption of technological and administrative innovations. Academy of Management Journal, 24(4), 689-713. http://dx.doi.org/10.2307/256170

Lin, C. Y. (2007). Factors affecting innovation in logistics technologies for logistics service providers in China. Journal of Technology Management in China, 2(1), 22-37. http://dx.doi.org/10.1108/17468770710723604

Lin, C. (2006). A study on the organizational innovations in Taiwan's logistics industry. The Business Review, Cambridge, 5(1), 270.

Marjuki, Ismail (2009),”Daya bunuh beberapa obat nyamuk bakar terhadap kematian nyamuk Anopheles Aconicus"

M.Z, Nur \& Abdul Wahab, Prof Dr Sazali \& Mamun, Abdullah \& Yaacob, Abu \& Kumar, Naresh \& Fazal, Syed. (2016). Defining the Concept of Innovation and Firm Innovativeness: A Critical Analysis from Resorce-Based View Perspective. International Journal of Business and Management. 11. 87-94. 10.5539/ijbm.v11n6p87.

Soelton, Mochamad, Nugrahati, Tati, 2018. How Complaining Behaviors Effect on Coping Stress and Anxiety?. International Journal of Saudi Journal of Business and Management Studies (SJBMS). Vol. 3, No. 6. 623-628.

Soelton et al, 2019. Gender : Stress Levels On Performance In Modern Industry. International Journal Archives of Business Research (United Kingdom). Vol. 7, No 2. 72-81

Soelton et al, 2018. Toward The Best Strategy In Minimizing The Spread of Drug Users. International Conference On Community Development In Asia. Vol 1. No 1. 171-176

Wijaya H. M. Hembing (1992), ”Tanaman Berkhasiat Obat di Indonesia”, Cet 1 ,Jakarta 